\title{
WELCOME to the World Stem Cell Report
}

\author{
Message from Bernard Siegel, Founder and Co-Editor- \\ in-Chief, World Stem Cell Report; Executive Director \\ of Genetics Policy Institute and Founder and Co-Chair, \\ World Stem Cell Summit.
}

The 2014 World Stem Cell Report reflects how stem cell research, while beginning as a local initiative, is indeed a global endeavor. With the transversal theme of "regional developments," we focus on complex regulatory, socioethical, and legal issues; meanwhile, we also highlight emerging trends. In addition, the report features novel scientific developments that are paving the path toward clinical translation.

The report benefits from the contribution of a wide range of multidisciplinary and international experts in the field. We seek to bring their knowledge together to look prospectively at new scientific, commercial, ethical, and policy developments. To this end, the Summit provides a unique picture of the international stem cell and regenerative medicine environments.

The 2014 World Stem Cell Report is aligned with the vision of this year's World Stem Cell Summit (San Antonio, Texas, December 3-5, 2014), the flagship event of the Genetics Policy Institute (GPI). The World Stem Cell Summit is a three-day showcase of innovation, insight, and inspiration. By uniting stem cell and regenerative medicine stakeholders, the Summit represents the largest interdisciplinary and networking meeting of this kind.

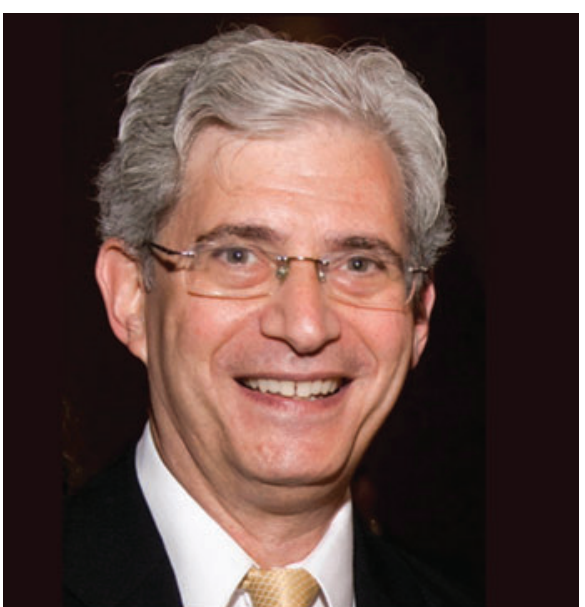

Bernard Siegel

We are pleased to distribute the report to the attendees of the 10th Anniversary World Stem Cell Summit, our largest summit to date. We thank the 2014 coorganizers-Mayo Clinic; Institute for Integrated Cell-Material Sciences (iCeMS), Kyoto University; the University of Texas Health Science Center at San Antonio; BioBridge Global; Baylor College of Medicine; and the Regenerative Medicine Foundation. We believe the report contributes to the collective mission of these wonderful institutions and the goals of those assembled in San Antonio, Texas, for the summit.

The World Stem Cell Report is dedicated to the millions of adults and children suffering from incurable diseases and medical conditions and their loyal advocates, as well as to the devoted scientists and clinicians all working together relentlessly toward finding a cure.

supplement to the peer-reviewed journal Stem Cells and Development. I want to express gratitude to my esteemed colleagues Dr. Graham Parker, editor-inchief of Stem Cells and Development, and Rosario Isasi, Centre of Genomics and Policy, Faculty of Medicine at McGill University, who served as our managing editor. I also want to recognize the contributions of Jayne Woolf, Corporate New Business Development at Mary Ann Liebert, Inc., and Alan Fernandez, associate director of GPI.
Let's Connect, Collaborate, and Cure!

Cordially,

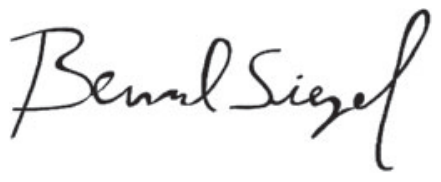

